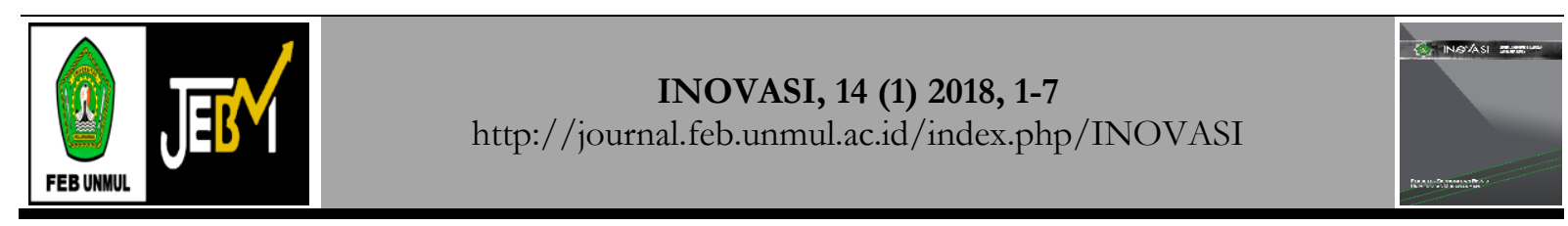

Pengaruh kompensasi dan motivasi terhadap kinerja karyawan

\author{
As'ad Syaifullah' ${ }^{1}$, Iwan Adhi Prasetyo ${ }^{2}$ \\ Fakultas Ekonomi dan Bisnis, Universitas Airlangga \\ Fakultas Ekonomi dan Bisnis, Universitas Negeri Surabaya \\ ${ }^{1}$ Email: asadsaifullah1@gmail.com \\ 2Email: asad_bolo@yahoo.com
}

\begin{abstract}
Abstrak
Penelitian ini dimotivasi oleh kurangnya kompensasi, yaitu upah, yang diberikan oleh PT. Prima Bumi Pakuwon Jaya kepada pekerja produksi yang tidak mempengaruhi kinerja kerja karyawan. Jumlah kompensasi yang diberikan oleh PT. Prima Bumi Pakuwon Jaya berada di bawah Upah Minimum Regional (UMR) Kabupaten Bojonegoro. Dengan demikian, penelitian ini dilakukan untuk menyelidiki pengaruh kompensasi dan motivasi terhadap kinerja kerja karyawan. Penelitian ini merupakan penelitian kuantitatif. Dalam menentukan sampel, peneliti menggunakan Non probability sampling dengan sampling jenuh karena populasi kurang dari 100 subyek (Arikunto, 1998: 112). Oleh karena itu, 80 karyawan produksi yang terdiri dari 63 perempuan dan 17 karyawan laki-laki dimasukkan sebagai sampel dalam penelitian ini. Instrumen yang digunakan untuk pengumpulan data adalah kuesioner dan dianalisis dengan regresi linier. Hasil penelitian ini menunjukkan bahwa kompensasi terutama jumlah upah secara parsial memberikan pengaruh positif terhadap kinerja kerja karyawan. Selanjutnya, motivasi juga secara parsial memberikan pengaruh positif terhadap kinerja kerja karyawan. Temuan penelitian ini menunjukkan bahwa kompensasi yang diberikan oleh PT. Prima Bumi Pakuwon Jaya sebanding dengan tingkat kesulitan pekerjaan berdasarkan sudut pandang karyawan produksi.
\end{abstract}

Kata Kunci: Kompensasi; upah; motivasi; performa kerja

\title{
The effect of compensation and motivation on employee performance
}

\begin{abstract}
This study is motivated by the lack of compensation, namely wages, given by PT. Prima Bumi Pakuwon Jaya to the production worker which does not adversely affect the employees' work performance. The amount of the compensation awarded by PT. Prima Bumi Pakuwon Jaya is under the Regional Minimum Wage (UMR) of Bojonegoro regency. Thus, this study was conducted to investigate the effect of compensation and motivation toward the employees' work performance. This research is a quantitative research. In determining the samples, the researcher used The non probability sampling with saturated sampling due to the population is less than 100 subjects (Arikunto, 1998:112). Therefore, 80 production employees consisting of 63 female and 17 male employees were included to be the sample in this study. The instrument used for the data collection was a questionnaire and analyzed by linear regression. The results of this study showed that the compensation especially the wage's amount partially gave positive effect toward the employees' work performance. Furthermore, the motivation is also partially gave positive effect toward the employees' work performance. The findings of this study showed that the compensation given by the PT. Prima Bumi Pakuwon Jaya is proportional to the difficulty level of the work based on the production employees' point of view.
\end{abstract}

Keywords: Compensation; wage; motivation; work performance 


\section{PENDAHULUAN}

Kinerja sumberdaya manusia atau dengan kata lain job perfomance adalah prestasi kerja atau prestasi sesungguhnya yang dicapai seseorang (Mangkunegara, 2006). Kinerja yang tinggi dari sumberdaya manusia di sebuah organisasi dapat menjadi keunggulan kompetitif dari organisasi tersebut. Pendapat tersebut sesuai dengan pendapat dari Tohardi (2002), yang menyebutkan bahwa apabila menggunakan strategi bersaing lewat sumberdaya manusia, maka akan diperoleh dua keunggulan kompetitif dan keunggulan komperatif, karena kedua keunggulan ini akan sulit ditiru oleh pesaing.

Sehubungan dengan persaingan dalam era globalisasi semakin hari dirasakan semakin ketat, manajemen sumber daya manusia sangat penting dan harus diperhatikan oleh pimpinan perusahaan untuk menjaga eksistensi perusahaannya. Untuk bisa menjaga keberhasilan dan kelangsungan hidup perusahaan maka seorang pemimpin harus menjaga dan meningkatkan sumberdaya yang dimilikinya termasuk didalamnya meningkatkan kinerja karyawan.

Kinerja merupakan suatu konstruksi multi dimensi yang mencakup banyak faktor yang mempengaruhinya seperti; pengetahuan, keterampilan, motivasi dan peran individu yang bersangkutan.

Lebih lanjut, menurut Handoko (2010), ada beberapa faktor prestasi kerja yang biasanya digunakan dalam perusahaan antara lain; kepribadian, sikap, ambisi, loyalitas, interest pada suatu perusahaan, tanggung jawab, disiplin, inisiatif, penyesuaian, kerja sama, pengetahuan pekerjaan, produktivitas kerja dan kepemimpinan. Sedangkan menurut Gibson (1987) dalam Suhendy dan Anggara (2010: 190), terdapat tiga faktor yang mempengaruhi kinerja yaitu:

Faktor individu: kemampuan, keterampilan, latar belakang keluarga, pengalaman kerja, dan tingkat sosial.

Faktor Psikologi: persepsi, peran, sikap, kepribadian, motivasi, dan kepuasan kerja.

Faktor Organisasi: struktur organisasi, desain pekerjaan, kepemimpinan dan sistem penghargaan.

Berdasarkan pendapat di atas maka, untuk meningkatkan kinerja karyawan dapat ditempuh melalai salah satunya sistem pemberian kompensasi yang layak dan meningkatkan motivasi karyawan.

Kompensasi sering dianggap sebagai penghargaan moneter dan non moneter, langsung dan tidak langsung yang diberikan kepada karyawan atas dasar nilai pekerjaan, kontribusi pribadi mereka, dan kinerja. Ini adalah salah satu kebutuhan fisik yang mempengaruhi motivasi yang pada gilirannya mempengaruhi kinerja karyawan. Tujuan dari kompensasi yang baik adalah untuk menarik, memotivasi dan mempertahankan orang-orang yang baik untuk pencapaian tujuan organisasi. Kompensasi dan motivasi harus diakui sebagai faktor utama yang mempengaruhi kinerja karyawan (Nilema and Nyaroo, 2013). Selain itu, motivasi yang tepat akan mendorong pegawai untuk berbuat semaksimal mungkin dalam melaksanakan tugasnya. Terlebih, motivasi yang tinggi akan menciptakan sebuat komitmen terhadap apa yang menjadi tanggung jawabnya dalam menyelesaikan setiap pekerjaannya. Motivasi memiliki hubungan yang erat dengan sikap dan perilaku yang dimiliki oleh seseorang. Sikap yang ada pada setiap individu berinteraksi dengan nilai-nilai, emosi, peran, struktur sosial dan peristiwa-peristiwa baru, yang bersama- sama emosi dapat dipengaruhi dan diubah oleh perilaku. Perubahan sikap ini dimungkinkan karena pikiran manusia adalah suatu kekuatan kompleks yang dapat mengadaptasi, mempelajari, dan memproses setiap informasi dan perubahan baru yang diterimanya. Motivasi itu sendiri dapat diartikan sebagai keadaan dalam diri pribadi seseorang sehingga orang tersebut terdorong untuk melakukan suatu kegiatan atau aktivitas. Beberapa penelitian terdahulu banyak mengungkap bahwa kompensasi merupakan salah satu faktor yang dapat memotivasi individu. Kompensasi itu sendiri adalah semua balas jasa yang diterima seorang karyawan dari perusahaan sebagai akibat dari jasa atau tenaga yang telah diberikannya pada perusahaan tersebut. Dalam penelitian ini, variabel motivasi dan kompensasi menjadi bahan pnelitian sebagai faktor yang mempengaruhi kinerja karyawan pada sebuah PT. Lebih khusus untuk kompensasi, peneliti mengambil satu jenis kompensasi yang zerupa upah. Sebagaimana Suryaningsih (2009:2) mengemukakan bahwa kompensasi juga merupakan penghargaan yang diberikan karyawan baik langsung maupun tidak langsung, finansial maupun non financial yang adi kepada karyawan atas sumbangan mereka dalam mencapai tujuan organisasi, sehingga pemberian kompensasi sangat dibutuhkan oleh perusahaan guna meningkatkan kinerja karyawannya. Kompensasi mencakup semua 
jenis pembayaran baik secara langsung maupun tidak langsung, berbentuk materil/uang maupun penghargaan yang diberikan perusahaan kepada pekerja/buruhnya. Penelitian ini mengambil satu jenis kompensasi yakni pembayaran langsung berbentuk finansial yang disebut dengan upah.

Dalam skripsi ini, peneliti mengambil fenomena yang tidak biasanya di mana di perusahaan PT. Prima Bumi Pakuwon Jaya Bojonegoro, perusahaan yang bergerak di bidang industri rokok ini, jumlah gaji yang diterima karyawan sangat jauh dari UMK Bojonegoro yaitu senilai Rp.1200.000,namun hal tersebut tidak berdampak buruk terhadap kinerja karyawan sebagaimana yang diungkapkan oleh Direktur Personalia PT. Prima Bumi Pakuwon Jaya Bojonegoro.

\section{Kajian Pustaka}

\section{Teori Kompensasi}

Menurut Rivai (2004:357) kompensasi merupakan sesuatu yang diterima karyawan sebagai pengganti kontribusi jasa mereka pada perusahaan. Pemberian kompensasi merupakan salah satu pelaksanaan fungsi manajmen sumber daya manusia yang berhubungan dengan semua jenis pemberian penghargaan individual sebagai pertukara dalam melakukan tugas keorganisasian. Kompensas merupakan hal yang sangat penting karena kompensasi yang cukup dapat menarik, memelihara dan menjaga karyawan agar tidak meninggalkan perusahaan.

Menurut Hasibuan, (2003:18), kompensasi adalah semua pendapatan yang berbentuk uang, barang langsung maupun tidak langsung yang diterima karyawan sebagai imbalan atas jasa yang diberikan kepada perusahaan Kompensasi berbentuk uang artinya kompensasi di bayar dalam bentuk uang kartal kepada karyawan bersangkutan. Kompensasi berbentuk barang artinya kompensasi dibayar dengan barang.

Untuk penggolongan Kompensasi, Hasibuan (2003:118) menyatakan, secara umum Kompensasi finansial dibagi menjadi dua yaitu:

\section{Direct Compensation}

Merupakan kompensasi yang diterima oleh karyawan yang mempunyai hubunga langsung denga pekerjaan yaitu, dalam bentuk gaji, upah, dan intensif.

\section{Indirect Compensation}

Merupakan kompensasi yang diterima oleh karaywan yang tidak mempunyai hubungan secara langsung dengan pekerjaannya antara lain, asuransi kesehatan, bantuan pendidikan, pembayaran selama cuti atau sakit.

Dalam penelitian ini, variabel kompensasi mengacu pada direct compensation direct compensation yang berupa upah.

\section{Teori Motivasi}

Luthans (1998) menegaskan bahwa motivasi adalah proses yang membangkitkan, memberikan energi mengarahkan, dan menopang perilaku dan kinerja. Sedangkan Hasibuan (2003:143) menyatakan bahwa motivasi adalah pemberian daya penggerak yang menciptakan kegerahan kerja seseorang agar mereka mau bekerja sama, bekerja efektif dan terintegrasi dengan segala daya upayanya untuk mencapai kepuasan. Pada hakekatnya pemberian motivasi kepada karyawan mempunyai tujuan yang dapat menigkatkan berbagai hal. Menurut Hasibuan (2003:146), berikut adalah beberapa pencapaian yang dapat diraih manakala suatu motivasi berhasil diberikan kepada karyawan:

Meningkatkan moral dan kemampuan kerja karyawan

Meningkatkan produktivitas karyawan

Mempertahankan kestabilan karyawan perusahaan

Meningkatkan kedisiplinan karyawan

Mengefektifkan pengadaan karyawan

Menciptakan suasana dan hubungan kerja yang baik

Meningkatkan loyalitas, kreativitas dan partisipasi karyawan

Meningkatkan tingkat kesejahteraan karyawan 
Mempertinggi rasa tanggung jawab karyawan terhadap tugas-tugaasnya.

\section{Teori Kinerja}

Menurut Mathis \& Jackson (2010), kinerja pegawai adalah apa yang dilakukan atau tidak dilakukan pegawai yang mempengaruhi seberapa banyak mereka memberi kontribusi kepada organisasi anatara lain kualitas output, kuantitas output, jangka waktu output, kehadiran ditempat kerja, dan sikap kooperatif. Sedangkan indikator kinerja menurut Gomes (2003) adalah sebagai berikut:

Kuantitas kerja: jumlah pekerjaan yang dihasilkan sesuai dengan target perusahaan.

Kualitas kerja: yaitu kualitas hasil pekerjaan yang sudah memenuhi standar perusahaan.

Kreativitas: keaslian idea tau gagasan yang dimunculkan dan tindakan untuk menyelesaikan pekerjaan.

Kerja sama: yaitu kemampuan untuk untuk bekerja sama dengan orang lain (sesama anggota organisasi).

Dependability: terkait bertanggung jawab atas pekerjaan yang dilakukan.

Inisiatif: semangat untuk melakukan tugas-tugas baru dan berinisiatif dalam melakukannya.

Kualitas pribadi: menyangkut kepribadian pekerja dalam melaksanakan pekerjaan sesuai dengan keahliannya.

Kedisiplinan dalam menyelesaikan pekerjaan sesuai yang di tentukan. Tingkat kejujuran dalam menyelesaikan pekerjaan sesuai dengan yang diharapkan. Ke tujuh indikator kinerja di atas menjadi bahan acuan pembuatan kuesioner dalam penelitian ini.

\section{Hubungan Antar Variabel}

\section{Hubungan Variabel Kompensasi terhadap Kinerja Karyawan}

Simamora (2004) mengatakan bahwa kompensasi dalam bentuk finansial adalah penting bagi karyawan, sebab dengan kompensasi ini mereka dapat memenuhi kebutuhannya secara langsung, terutama kebutuhan fisiologinya. Namun demikian, tentunya pegawai juga berharap agar kompensasi yang diterimanya sesuai dengan pengorbanan yang terlah diberikan dalam bentuk non finansial juga sangat penting bagi pegawai terutama untuk pengembangan karir mereka. Lebih lanjut, Hameed et.al (2014) menuturkan bahwa kompensasi, baik dalam bentuk gaji, bonus, maupun penghargaan tertentu, terbukti dapat meningkatkan kinerja karyawan.

\section{Hubungan variabel Motivasi Kerja terhadap Kinerja Karyawan}

Mathis \& Jackson (2010) menyatakan bahwa motivasi adalah suatu dorongan di dalam diri seseorang yang menyebabkan seseorang mau bergerak atau bertindak. Dalam hubungannya antara variabel motivasi terhadap kinerja karyawan, Haider et.al (2012) menyatakan bahwa motivasi adalah hal yang krusial yang mempengaruhi perilaku manusia. Sehingga, Haider (2012) menggarisbawahi bahwa pimpinan kerja sudah selayaknya mengetahui faktor apa saja yang mempengaruhi motivasi bekerja karyawannya karena motivasi adalah kunci untuk meningkatkan kinerja karyawan sesuai dengan visi dan misi perusahaan.

\section{Hipotesis}

Hipotesis dalam penelitian ini adalah:

H1: Kompensasi berpengaruh terhadap kinerja karyawan

H2: Motivasi kerja berpengaruh terhadap kinerja karyawan

H3: Kompensasi dan motivasi kerja berpengaruh terhadap kinerja karyawan.

Interview (Wawancara)

Obeservasi (Pengamatan)

Penyebaran Angket (Kuesioner) Teknik Analisis Data

\section{Regresi Linier Berganda}

Menurut Algifari (2002: 61), model regresi linier berganda dikembangkan untuk mengestimasi nilai variabel dependen $(Y)$ dengan menggunakan lebih dari satu variabel independen $(X)$ sehingga persamaan regresi berganda dapat ditulis sebagai berikut:

$\mathrm{Y}=\mathrm{a}+\mathrm{b} 1 \mathrm{X} 1+\mathrm{b} 2 \mathrm{X} 2+\mathrm{e}$

Koefisien Determinasi Berganda $\left(\mathrm{R}^{2}\right)$ 
Menurut Algifari (2002: 46), koefisien determinasi $\left(\mathrm{R}^{2}\right)$ adalah satu dikurangi rasio antara besarnya nilai $\mathrm{Y}$ observasi dari garis regresi dengan besarnya deviasi nilai $\mathrm{Y}$ observasi dari rataratanya. Secara matematis dapat ditulis sebagai berikut:

$\mathrm{R}^{2}=1-\Sigma(\mathrm{Y}-\hat{\mathrm{Y}}) \Sigma(\mathrm{Y}-\hat{\mathrm{Y}})^{2}$ Jenis penelitian ini adalah penelitian kuantitatif. Pengambilan sampel dalam penelitian ini menggunakan metode nonprobability sampling dengan sampling jenuh karena populasi kurang dari 00 subjek (Arikunto, 1998:112). Maka, 80 karyawan bagian produksi yang terdiri dari 63 karyawan berjenis kelamin perempuan dan 17 karyawan berjenis kelamin laki-laki menjadi sampel dalam penelitian ini. Instrumen yang digunakan untuk pengambilan data adalah angket dan dianalisis dengan regresi linier berganda. Variabel yang digunakan dalam penelitian ini adalah variabel dependen $(\mathrm{X})$ dan variabel independen $(\mathrm{Y})$, variabel dependen dalam penelitian ini adalah Kompensai (X1) dan Motivasi kerja (X2) sedangkan variabel independenya adalah Kinerja karayawan (Y).

\section{METODE}

Kegiatan Pengumpulan data dalam penelitian merupakan suatu hal yang penting. Metode pengumpulan data dapat dilakukan dengan cara interview (wawancara), Observasi (pengamatan), Kuesioner (angket). Dan gabungan ketiganya (Sugiyono 2012:137)

Adapaun metode pengumpula data yang digunaka dalam penelitian ini dilakukan dengan tahaptahap sebagai berikut:

Bila nilai $\mathrm{R}^{2}$ semakin mendekati 1 atau $100 \%$, berarti semakin baik model regresinya dalam menjelaskan variabilitas variabel terikat.

\section{HASIL DAN PEMBAHASAN}

Penelitian ini adalah penelitian kuantitatif. Pengambilan sampel dalam penelitian ini menggunakan metode nonprobability sampling dengan sampling jenuh karena populasi kurang dari 100 subjek (Arikunto, 1998:112). Maka, 80 karyawan bagian produksi yang terdiri dari 63 karyawan berjenis kelamin perempuan dan 17 karyawan berjenis kelamin laki-laki menjadi sampel dalam penelitian ini. Instrumen yang digunakan untuk pengambilan data adalah angket dan dianalisis dengan regresi linier berganda.

Tabel 1. Hasil Tanggapan Karyawan bagian produksi

\begin{tabular}{|c|c|c|c|c|}
\hline No & Pernyataan & Mean & Std. Dev & Kategori \\
\hline 1 & Gaji yang diterima memuaskan sehingga saya lebih giat dalam bekerja & 3.48 & 1.091 & Setuju \\
\hline 2 & Saya menerima gaji sesuai dengan keahlikan yang saya miliki & 3.84 & 1.137 & Setuju \\
\hline 3 & $\begin{array}{l}\text { Menurut saya, bayaran yang diberikan perusahaan sesuai dengan } \\
\text { tanggung jawab masing-masing karyawan }\end{array}$ & 3.53 & 1.113 & Setuju \\
\hline 4 & $\begin{array}{l}\text { Gaji yang diberikan oleh perusahaan sesuai dengan tingkat pendidikan } \\
\text { yang dimiliki oleh karyawannya }\end{array}$ & 3.74 & 1.052 & Setuju \\
\hline 5 & $\begin{array}{l}\text { Masa kerja karyawan mempengaruhi tingkat gaji yang diberikan oleh } \\
\text { perusahaan }\end{array}$ & 3.63 & 1.084 & Setuju \\
\hline 6 & $\begin{array}{l}\text { Prestasi kerja karyawan mempengaruhi tingkat penentuan bayaran yang } \\
\text { diberikan oleh perusahaan kepada karyawan. }\end{array}$ & 3.63 & 1.023 & Setuju \\
\hline 7 & $\begin{array}{l}\text { Menurut saya, perusahaan membayar saya sesuai dengan metode yang } \\
\text { ditentukan oleh perusahaan }\end{array}$ & 3.61 & 1.037 & Setuju \\
\hline 8 & Perusahaan membayar saya sesuai dengan hasil kinerja saya & 3.63 & 1.095 & Setuju \\
\hline 9 & $\begin{array}{l}\text { Perusahaan membayar saya sesuai dengan penentuanubahan upah } \\
\text { minimum karyawan }\end{array}$ & 3.71 & 0.917 & Setuju \\
\hline \multicolumn{2}{|r|}{ Mean Secara Keseluruhan Variabel Kompensasi (X1) } & 3.64 & 1.061 & Setuju \\
\hline
\end{tabular}

Sumber: Data diolah 
Tabel 2. Hasil Tanggapan Karyawan bagian produksi

\begin{tabular}{|c|c|c|c|c|}
\hline No & Pernyataan & Mean & Std. Dev & Kategori \\
\hline 1 & $\begin{array}{l}\text { Saya berusaha dengan sangat sungguh- sunggguh untuk meningkatkan } \\
\text { kinerja. }\end{array}$ & 3.50 & 0.981 & Setuju \\
\hline 2 & Saya menikmati tatantangan pekerjaan yang sulit. & 3.54 & 0.810 & Setuju \\
\hline 3 & $\begin{array}{l}\text { Perusahaan memberikan alat keselamatan kerja ada saat proses produksi } \\
\text { berlangsung }\end{array}$ & 3.49 & 0.994 & Setuju \\
\hline 4 & Saya menikmati kepuasan dari penyelesaian pekerjaan yang sulit. & 3.66 & 0.899 & Setuju \\
\hline 5 & $\begin{array}{l}\text { Besarnya penghasilan dari perusahaan dapat mencukupi kebutuhan saya } \\
\text { sehari-hari. }\end{array}$ & 3.49 & 0.981 & Setuju \\
\hline 6 & $\begin{array}{l}\text { Perusahaan memberikan kebebasan untuk melakukan istirahat pada } \\
\text { waktu yang telah ditentukan. }\end{array}$ & 3.45 & 1.005 & Setuju \\
\hline 7 & $\begin{array}{l}\text { Perusahaan menjamin kenaikan jabatan terhadap karyawan yang } \\
\text { memiliki potensi dan masa kerja yang telah ditentukan. }\end{array}$ & 3.40 & 0.908 & Setuju \\
\hline 8 & $\begin{array}{l}\text { Perusahaan memberikan dukungan penyelesaian masalah jika karyawan } \\
\text { mendapat kesulitan atau masalah dalam bekerja. }\end{array}$ & 3.60 & 1.038 & Setuju \\
\hline Me & an Secara Keseluruhan Variabel Motivasi Kerja $\left(\mathbf{X}_{2}\right)$ & 3.52 & 0.952 & $\begin{array}{l}\text { Sangat } \\
\text { Setuju }\end{array}$ \\
\hline
\end{tabular}

Sumber: Data diolah

Berdasarkan pada tabel 4.5 di atas dapat dijelaskan bahwa hasil tanggapan karyawan bagian produksi PT. Prima Bumi Pakuwon Jaya Bojonegoro akan variabel Kompensasi (X1) sebagian besar menyatakan pernyataan berikut "Saya menerima gaji sesuai dengan keahlian yang saya miliki", dengan memiliki nilai rata-rata tertinggi sebesar 3.84. Hal ini menunjukan bahwa karyawan bagian produksi PT. Prima Bumi Pakuwon Jaya Bojonegoro mampu memberikan kompensasi dengan sebaikbaiknya. Sedangkan secara keseluruhan nilai rata-rata tanggapan karyawan bagian produksi PT. Prima Bumi Pakuwon Jaya Bojonegoro tentang seluruh variabel Kompensasi tersebut sebesar 3.64. Dalam interval kelas termasuk dalam kategori 3,40 $\leq \mathrm{x}<4,20$, yang menunjukkan karyawan bagian produksi PT. Prima Bumi Pakuwon Jaya Bojonegoro memberi penilaian baik atas pernyataan tentang semua variabel Kompensasi.

Berdasarkan pada tabel 4.6 di atas dapat dijelaskan bahwa hasil tanggapan karyawan bagian produksi PT. Prima Bumi Pakuwon Jaya Bojonegoro akan variabel motivasi kerja (X2) sebagian besar menyatakan pernyataan berikut "Saya menikmati kepuasan dari penyelesaian pekerjaan yang sulit.", dengan memiliki nilai rata-rata tertinggi sebesar 3.66. Hal ini menunjukkan bahwa karyawan bagian produksi PT. Prima Bumi Pakuwon Jaya Bojonegoro memotivasi diri saat bekerja. Se 7 dangkan secara keseluruhan nilai rata-rata tanggapan karyawan bagian produksi PT. Prima Bumi Pakuwon Jaya Bojonegoro tentang seluruh variabel motivasi kerja tersebut sebesar 3.52. Dalam interval kelas termasuk dalam kategori 4,20 $\leq \mathrm{x}<5,00$, yang menunjukkan karyawan bagian produksi PT. Prima Bumi Pakuwon Jaya Bojonegoro memberi nilai Setuju atas pernyataan tentang semua variabel motivasi kerja.

\section{Pembahasan}

Berdasarkan hasil penelitian didapatkan bahwa variabel Kompensasi memiliki pengaruh secara parsial terhadap Kinerja Karyawan bagian produksi PT. Prima Bumi Pakuwon Jaya Bojonegoro, hal ini dapat diketahui dari nilai thitung sebesar 8.726 lebih besar dari ttabel sebesar 1.99125 maka H0 ditolak pada tingkat signifikansi 5\% sehingga kesimpulannya adalah variabel Kompensasi (X2) mempunyai pengaruh sig $\neg n i f i k a n$ positif terhadap Kinerja Karyawan di PT. Prima Bumi Pakuwon Jaya Bojonegoro. Hal ini menunjukkan bahwa semakin tinggi Kompensasi yang dimiliki oleh karyawan maka akan semakin tinggi pula Kinerja Karyawan tersebut dengan memberikan hasil kerja yang optimal baik secara kualitas maupun kuantitas. Hasil dalam penelitian ini mendukung penelitian yang dilakukan oleh Mathis dan Jackson (2010) bahwa salah satu cara manajemen untuk meningkatkan prestasi kerja, memotivasi dan meningkatkan kepuasan kerja para karyawan adalah melalui kompensasi. Secara sederhana kompensasi merupakan sesuatu yang diterima karyawan untuk balas jasa kerja mereka. Hasil dalam penelitian ini juga sesuai dengan hasil penelitian yang dilakukan oleh Simamora (2004) mengatakan bahwa kompensasi dalam bentuk finansial adalah penting bagi karyawan, sebab dengan kompensasi ini mereka dapat memenuhi kebutuhannya secara langsung, 
terutama kebutuhan fisiologinya. Namun demikian, tentunya pegawai juga berharap agar kompensasi yang diterimanya sesuai dengan pengorbanan yang terlah diberikan dalam bentuk non finansial juga sangat penting bagi pegawai terutama untuk pengembangan karir mereka. Lebih lanjut, Hameed et.al (2014) menuturkan bahwa kompensasi, baik dalam bentuk gaji, bonus, maupun penghargaan tertentu, terbukti dapat meningkatkan kinerja karyawan. Berdasarkan hasil penelitian juga didapatkan bahwa variabel Motivasi Kerja memiliki pengaruh secara parsial terhadap Kinerja Karyawan bagian produksi PT. Prima Bumi Pakuwon Jaya Bojonegoro, hal ini dapat diketahui dari nilai thitung sebesar 2.124 lebih besar dari ttabel sebesar 1.99125 maka H0 ditolak pada tingkat signifikansi 5\% sehingga kesimpulannya adalah variabel Motivasi Kerja (X2) mempunyai pengaruh sig $\neg$ nifikan positif terhadap Kinerja Karyawan di PT. Prima Bumi Pakuwon Jaya Bojonegoro. Hal ini menunjukkan bahwa semakin tinggi Motivasi Kerja yang dimiliki karyawan maka akan meningkatkan Kinerja Karyawan dengan sebaik - baiknya. Dengan kata lain, semakin tinggi Motivasi Kerja yang dirasakan oleh karyawan dalam melaksanaan pekerjaan maka akan semakin tinggi Kinerja Karyawan tersebut. Secara garis besar, hasil penelitian menunjukkan bahwa kompensasi berpengaruh positif secara parsial terhadap kinerja karyawan, dan motivasi berpengaruh positif secara parsial terhadap kinerja karyawan. Terkait dengan rendahnya nilai kompensasi yang diberikan oleh perusahaan, karyawan bagian produksi pada PT. Prima Bumi Pakuwon Jaya menilai bahwa upah atau kompensasi yang mereka terima sebanding dengan tingkat kesulitan pekerjaan atau beban kerja yang diberikan. Sehingga, rendahnya kompensasi yang diberikan oleh perusahaan tidak menyebabkan penurunan kualitas kinerja karyawan ataupun rendahnya motivasi dalam bekerja.

\section{SIMPULAN}

Dalam penelitian ini kompensasi karyawan pada PT. Prima Bumi Pakuwon Jaya yang berada di bawah UMK kota Bojonegoro tidak menimbulkan efek negatif terhadap kinerja karyawan. Hasil penelitian justru menunjukkan bahwa kompensasi yang diberikan perusahaan dinilai layak oleh karyawan pada PT. Prima Bumi Pakuwon Jaya Bojonegoro. Layak dalam hal ini mengacu pada keseimbangan antara beban kerja dan kompensasi yang diterima. Hal ini menunjukkan bahwa terdapat adanya perbedaan pengukuran besar kecilnya nilai kompensasi di mata karyawan PT. Prima Bumi Pakuwon Jaya Bojonegoro dengan nilai kompensasi yang ditetapkan oleh Pemerintah di kota tersebut.

\section{DAFTAR PUSTAKA}

Anwar, P. Mangkunegara, 2006. Manajemen Sumber Daya Manusia. Bandung: Remaja Rosdakarya.

Arikunto, S. 1998. Prosedur Penelitian Suatu Pendekatan Praktek. Jakarta: PT. Rineka. Cipta.

Tohardi, A. (2002). Pemahaman Praktis Manajemen Sumber Daya Manusia. Bandung: Universitas Tanjung Pura.

Handoko, Hani. 2001. Manajemen, Yogyakarta:BPFE Nelima, J., \& Nyaroo, S. (2013). Effect of Compensation on Performance of Public Secondary School Teachers in Eldoret Municipality Kenya. International Journal of Scientific and Research Publications, 3(6)

Rivai, V. (2005). Manajemen Sumber Daya Manusia untuk Perusahaan dari Teori ke Praktik. Jakarta: Raja Grafindo Persada.

Hasibuan, Melayu, 2003. Manajemen Sumber Daya Manusia, Cetakan ketujuh, Jakart, PT. Bumi Aksara

Luthans, F. (1998). Organisational Behaviour. 8th ed. Boston: Irwin McGraw-Hill.

Mathis, R. L., \& Jackson, J. H. (2010). Human Research Management. South Western: Cengage Learning. Gomes, Faustino Cardoso, (2003). Manajemen Sumber Daya Manusia. Yogyakarta: Andi Offest.

Simamora, H. (1995). Manajemen Sumber Daya Manusia. Yogyakarta: STIE YPKN.

Haider, A. A. M. A. J. (2012). Impact of Motivation on the working performance of employees- A case study of Pakistan. Global Advanced Research Journal of Management and Business Studies, 1(4). 